第64回日本内科学会講演会（1967年）

\title{
シンポジウム ポルフィリン症の臨床
}

（1）肝性ポルフィリン症の臨床と疫学

新渴大学松岡内科救室

講師佐々 木英大

\section{SYMPOSIUM ON CLINICAL ASPECTS ON PORPHYRIAS \\ (1) CLINICAL AND EPIDEMIOLOGICAL STUDIES OF HEPATIC PORPHYRIA IN JAPAN}

Hideo Sasaki M.D.

The First Department of Internal Medicine,

Niigata University School of Medicine, Niigata

はじめに

ポルフィリン症の研究は近年急速に進み, 最近 では遗伝性代謝疾患の中で最も進んだ分野となつ ている．本症の分類はまだ論議も多いが，一応表 1 の如く要約できる。すなわちポルフィリン代謝 異常の場の相違から骨䯣性ポルフィリン症と肝性 ポルフィリン症に大別される，骨髄性ポルフィリ
ン症は增加したポルフィリンの種類により３型に 分けられ, 肝性ポルフィリン症は遺伝性の有無か ら2 分され，さらに増加したポルフィリン体の種 類や原因により細分されている，一方症候面から は腹痛, 四肢麻痺, 精神症状などを呈する急性ポ ルフィリソ症と光線過敏性を特徽とする皮膚ポル フィリン症に分けられる。中であ急性ポルフィリ

表 1. Porphyrin症の分類

\begin{tabular}{|c|c|c|c|}
\hline & \multirow{2}{*}{ Biochemical } & \multicolumn{2}{|c|}{ Symptomatic } \\
\hline & & Acute & Cutaneous \\
\hline I. Porphyria erythropoietica & & & \\
\hline $\begin{array}{l}\text { 1) P. congenita Günther } \\
\text { 2) Protoporphyria erythropoietica } \\
\text { 3) Coproporphyria erythropoietica }\end{array}$ & $\begin{array}{l}\text { Uro(Copro) porphyria } \\
\text { Protoporphyria } \\
\text { Coproporphyria }\end{array}$ & $(\stackrel{(-)}{(-)}$ & $\begin{array}{l}(++) \\
(+) \\
(+)\end{array}$ \\
\hline I. Porphyria hepatica & & & \\
\hline $\begin{array}{l}\text { a) hereditary forms } \\
\text { 1) P.acuta intermittens } \\
\text { 2) P. variegata or mixed P. } \\
\text { 3) PCT hereditaria ? } \\
\text { 4) Coproporphyria hereditaria }\end{array}$ & $\begin{array}{l}\text { Pyrrolia } \\
\text { Protocoproporphyria } \\
\quad \text { " } \\
\text { Coproporphyria }\end{array}$ & $\begin{array}{l}(+) \\
(t) \\
(t)\end{array}$ & $\begin{array}{l}(-) \\
(+) \\
(+)\end{array}$ \\
\hline $\begin{array}{l}\text { b) acquired forms } \\
\text { 1) PCT symptomatica } \\
\text { 2) Bantu Porphyria } \\
\text { 3) Fungicide( Hexachlorbenzene) } \\
\text { 1) Porphyrin producing hepatic } \\
\text { adepoma } \\
\text { 5) Griseofulvin }\end{array}$ & $\begin{array}{c}\text { Uroporphyria } \\
\text { " }\end{array}$ & $\begin{array}{l}(-) \\
(-) \\
(-) \\
(-)\end{array}$ & $\begin{array}{l}(t) \\
(t) \\
(t) \\
(t) \\
(t)\end{array}$ \\
\hline
\end{tabular}


ン症は肝性に限られている。

演者は肝性ポルフィリン症の中, 最も頻度の多 い急性ポルフィリン症につき，自験例を中心に 本邦症例を総括し, 臨床知見, 疫学的事項拉よび hereditary coproporphyriakつき報告する。

\section{I. 臨床的事項について}

自験19例を中心に, 文献拉よび今度の関東甲信 越以北の地区のアンケート調查の結果から本邦症 例をまとめて報告する。

\section{1）誘因}

急性ポルフィリン症が遗伝性疾患であることは 周知の事実であるが，しばしば誘因が認められ る、薬物ではバルビタール剂が最も多く, 感染症 や月経前期, 妊娠早期などにも多い。しかし，発 症は感冒時のバルビタール剤服用や妊娠時の過労 など二つ以上の誘因が重なつた場合が多い．

2) 初発症状

多くの症例では軽い症状が $4 \sim 5$ 日先駆する. 腹部鈍痛〜呕吐, 頭痛〜筋痛, 不眠〜不安などが 多く初期の3 徵とい之よう。

3) 主要症状（図1）

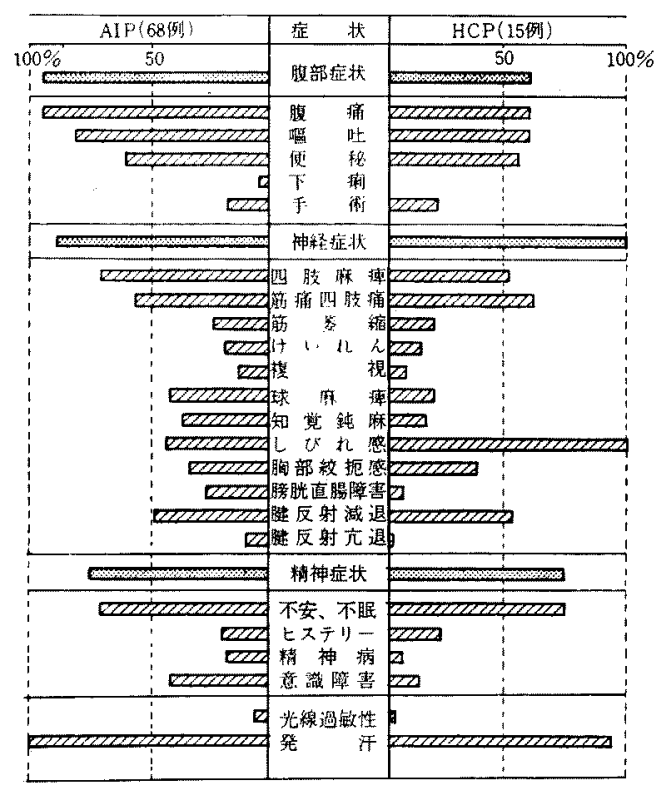

図1。主要蹦㾁症状
本症の極期症状をみると，腹部症状，神経症 状，精神症状心順に多く，それぞれ70\%以上を占 め, いわゆる3 徵が認められる。腹部症状では腹 痛, 呕吐, 便秘 のGüntherの 3 徵が主体をなし, 神経症状では脱力〜四肢麻㾇，能痛～神経痛，乙 び扎感が多く，精神泟状では不眠〜不安が多い。 症状の組合世を及ると，3徵を揃党るものが大半 であるが，不全型も40\%とかなり多く，中でも腹 痛を欠く例が $10 \%$ あることは注意を要する。症 状の経過は腹部激痛一鈍痛, 不安一譫妄, 雷腄,

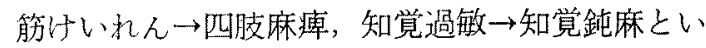
ずれも刺激症状から麻痺症状への経過をたどる㑯 向が認められる。したがって病状は時期によつて もかなり異るため種々の疾患と誤診されている。 すなわら，初期は腹部激痛，呕吐が目立ち，急性 腹症と䛊られ，開腹手術を受けるものが多く，女 性では娃娠覀阻などと乎䛊診される。病状が進む と，四肢麻痺，球麻疸などが前景に立ち，種々の 神経，筋疾患と誤ら杞る。またこの間に精神症 状が次第に加ふり，多訴的な割に所見が少なく， かつ日によつて動摇するため, 神経症やヒステリ 一などと誤診される場合も多い。

\section{4）臨床娭查成績（図 2 ）}

発症期尿porphobilinogen(PBG) お゙よびポルフ イリンは $100 \%$ 陽性で䛦断に役立つ.このほか,半 数例以上に㪊められる異常所見は高血生, 頻脈, 乏尿, ブドウ酒色尿, 血沈促進, 心電図, 脳波, 胃X線像の異常など，B S P の高值, アグロブリ ンの增加, 血清コレステロール増加, 高血糖, 低 $\mathrm{Na}$ 血症, 低 $\mathrm{Cl}$ 血症, 尿クレアチン増加などがある が，中でも高血圧，頻脈，脳波異常，高コレステ ロール血症, 低 $\mathrm{Na}$ 血症などは病状の消長と平行 し，経過の上い指標となる。をた高血糖は成長ホ ルモンの過分泌，低Na血症は抗利尿ホルモン過分 泌に上ると推定されて招り，脳波の徐波傾向と相 まつて本症の極期には一過性の間脳障害が推測さ 机た。

\section{Hereditary coproporphyriaについて} ポルフィリン体の変動からみると, 肝性ポルフ 


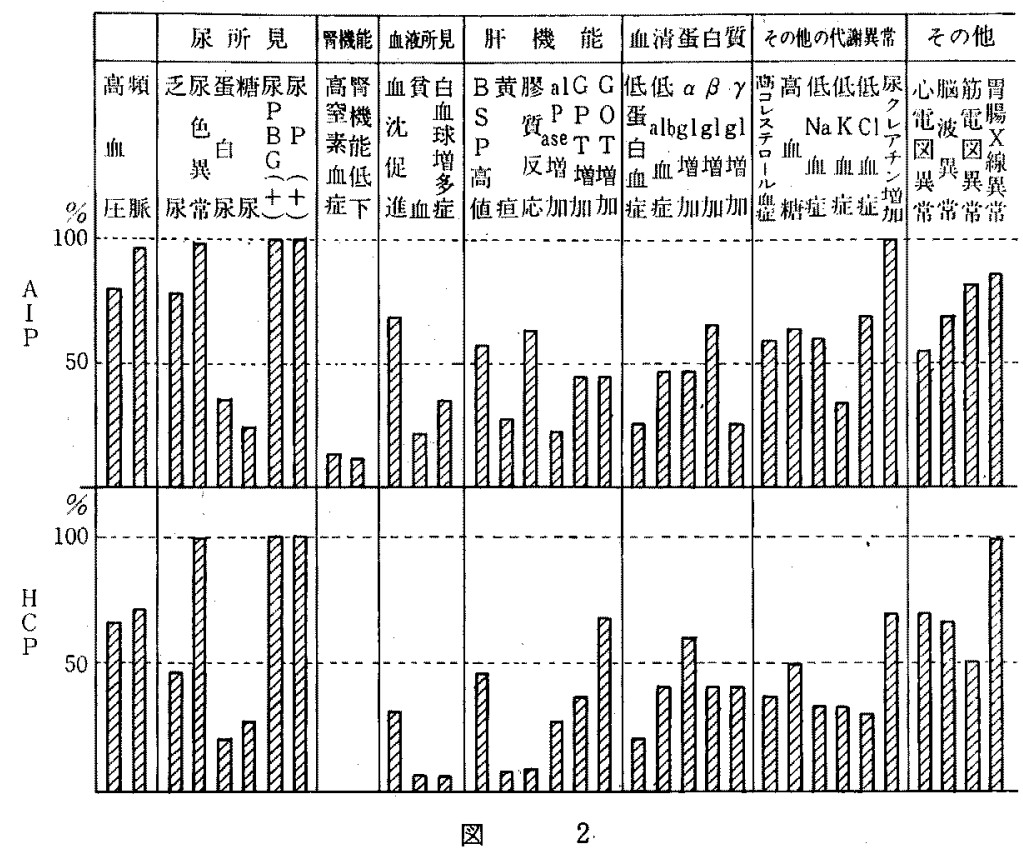

表 2. Hereditary coproporphyria（自娩例）

\begin{tabular}{|c|c|c|c|c|c|c|c|c|c|c|c|}
\hline & \multirow{2}{*}{$\begin{array}{l}\text { 作命 } \\
\text { 性 }\end{array}$} & \multirow{2}{*}{ 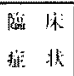 } & \multicolumn{4}{|c|}{$(\mathrm{mg} / \mathrm{H})$ 永 $(\mu \mathrm{g} / \mathrm{\theta})$} & \multicolumn{2}{|c|}{ 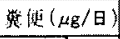 } & \multicolumn{2}{|c|}{ 赤血炼 $(\mathrm{kg} / \mathrm{d} \mathrm{d})$} & \\
\hline & & & $\mathrm{ALA}$ & PBG & $\mathrm{UP}$ & $\mathrm{CP}$ & $\mathrm{CP}$ & P P & $\mathrm{CP}$ & P P & \\
\hline \multirow{2}{*}{ 1.Y.Y. } & \multirow{2}{*}{44 우 } & 発悑: 斯 & 67.0 & 44.0 & 6100 & 8100 & 70460 & 3446 & & & \multirow{2}{*}{ 家采に瓷缏 $\mathrm{P}(+) 6$ 名 } \\
\hline & & 峨解則 & 0.3 & 0.2 & 349 & 3038 & 24913 & 617 & & & \\
\hline \multirow{2}{*}{ 2. M. M. } & \multirow{2}{*}{289} & 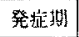 & 45.0 & 67.5 & 1123 & 3060 & 50429 & 1042 & 4.1 & 28.0 & \multirow{4}{*}{ 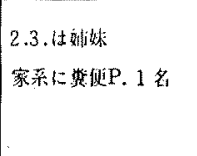 } \\
\hline & & 楥解期 & 2.4 & 1.2 & 11 & 64 & 21900 & 588 & & & \\
\hline \multirow{2}{*}{ 3. K. M. } & \multirow{2}{*}{$32 \%$} & 淀期 & 22.3 & 56.8 & 142.6 & 1800 & 49888 & 1640 & & & \\
\hline & & 㖟解楽! & 1.1 & 1.0 & 49 & 514 & 6180 & 121 & 1.64 & 28.6 & \\
\hline & 35 우 & 㖟解恝 & 0.3 & 0.7 & 0 & 49 & 52406 & 3688 & & & 昭敷37 \\
\hline \multirow{2}{*}{ 5. H. H. } & \multirow{2}{*}{38 ㅇ } & 発雃㯕 & 11.9 & 73.1 & 1054 & 8242 & 138000 & 3290 & 3.82 & 20.1 & \multirow{2}{*}{ 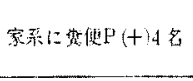 } \\
\hline & & 秷解撕 & 0.7 & 1.9 & 38 & 293 & 22173 & 741 & 3.20 & 22.4 & \\
\hline T. T. & 46 ? & 絿解期 & 0.8 & 1.5 & 53 & 722 & 16600 & 230 & 3.40 & 49.0 & 18 \\
\hline \multirow{2}{*}{ ־.K. H. } & \multirow{2}{*}{$26+9$} & 発庭期 & 13.3 & 138.7 & 1025 & 9811 & 49900 & 1075 & & & \multirow{2}{*}{ 家采に擎健P (十)4 名 } \\
\hline & & 粰解期 & 1.4 & 1.4 & 78 & 482 & 9610 & 257 & 1.2 & 35.2 & \\
\hline. & 21 ㅇ & 発症期 & & $(H)$ & & & 52260 & 1790 & & & 家蒜に繁便P $(+1)$ 名 \\
\hline
\end{tabular}

イリン症は赤血球ポルフィリン体の增加しない点 で骨髄性ボルフィリン症と著しく異なる．肝性ポ ルフィリン症の中, 急性症状を呈する。のは尿 $\mathrm{P}$ B G の増加が共通し，これまで䋸解期です尿 P B $\mathrm{Gが}$ 高值を示す acute intermittent porphyria(AIP) と粪便protoporphyrin (PP) と coproporphyrin(CP) の高値を示すvariegate porphyria (VP, Dean \&
Barnse)の 2 病型が知られている.啳者は光線過敏 性も呈し, mixed porphyria(Watson) pporphyria cutanea tarda hereditaria (Waldenström) との異 同など若千問題もあるが，metabolicには同一とみ なされる。

われわれは最近，これらの病型とも異なり，粪 便C Pの年增加する新病型hereditary copropor- 
phyria(HCP)を経駼したので報告する。

症例は8例, 全て女性である。症例2，3怢妹 であり，全例家族に潜在症を钽める(表2)。症状 は図 1 ○如く腹痛，呕吐，四肢麻㿇，精神症状な どを示し，AＩＰとほぼ同様であるが，その組合 せで腹部症状を欠くめのが $40 \%$ とかなり多く，逆 に神経症状が多く，中でもしび秃感は必発である。

ポルフィリン体の変動をみると尿 P B Gは発症 期平均67.1mg/日（44.0〜 $138.7 \mathrm{mg} /$ 日）と著增する が，緩解期では怕均 $1.1 \mathrm{mg} /$ 日 $(0.2 \sim 1.9 \mathrm{mg} /$ 日) 正常值上なつている.一力, 貨便ポルフィリンでは C P の及が発症期平均86.7mg/日 (49.9 138.0mg /日)と箸增し，緩解期でも半均 $18.6 \mathrm{mg} /$ 日 ( $6.2 \sim$ 52.4) と減少するがなお高值を持続しているのに 対し，P Pの増加は終始認められず，本病型の特 徵と考兄られた。この増加したC $\mathrm{P}$ は同定の結果 C P IIIであることが確かめられた。 また赤血球 C $\mathrm{P}$ 抢よび P P 增加もなく, 骨顝赤芽球の $\delta$-aminolevulinic acid合成䤃素活性の增加もなく， ポ ルフィリン体の異常産生部位は骨䯣以外であり, 恐らく肝に由来するものと考完られた。

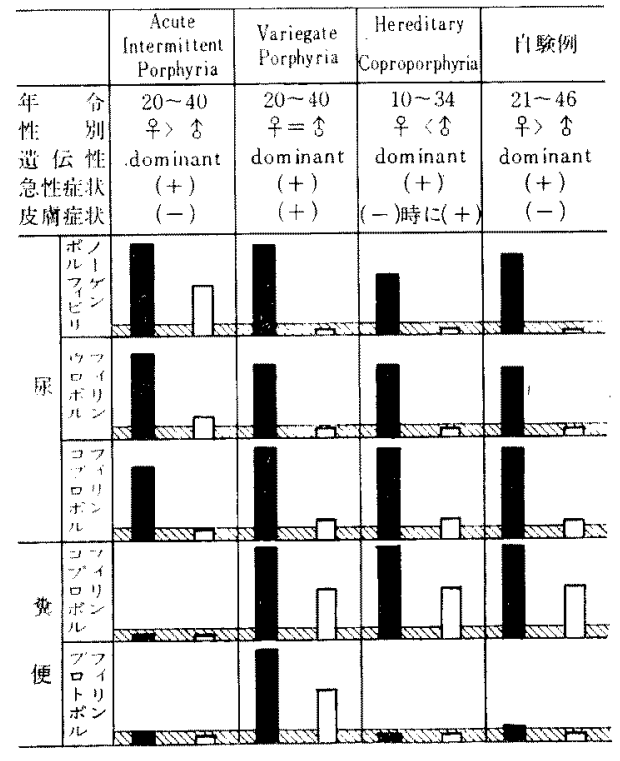

$\square$ 緩解期

口発症期

图 3. Acute porphyriaの比较検討 同様の䇥例はこれまでchronic porphyria (Dobrincr), idiopathic coproporphyrinuria(Watson), hereditary coproporphyria (Berger, Barnse) ts として6 例が報告されているが，当初は無症状 で肝性か骨随性か子不明とされていた。最近， Barnseらは急性症状を旺する例を, Langhofらは急 性症状乞皮䖉症状を呈寸る例を報告しており，恐 らく肝性に属与るものと推定されている。図3は これらの症例を含めた急性ポルフィリン症とわれ われの症例を比較检諨したものである，年令がや や高く，女性に多く，急性症を呈し，加光線過钦 性を炎く点ではHCPよりはAI PK類似する。 しかし，ボルフィリン体の変動からみると緩解期 㭧P B Gの增加しない点ではA I P とは明らかに 翼なる。むしる筫便ポルフィリンの增加してい る点ではV Pに類似するがC Pのみ増加し, P P が全く增加しない点で異なり, 新病型hereditary coproporphyriaに属吉るものと考えられた。

\section{III. 疫学的事項について}

\section{1）本邦症例の総括}

本病型を考虑して，本邦症例をまとめてみる と，急性ポルフィリン症の報告は昭和36年以来， 急增して扣り, 現在までA I Pと思わ机るもの68 例，VPと思われるもの8例，HCPは8例であ る。性别ではA I P, HCPは女性に多く, V P は男性に多い傾向があり，年令ではA I Pは20〜 40才に80\%が集中しているが，VP，HCPはや や高年に分布している。またＩＰはほぼ全国に 分布しているが，とくに新潟，大阪，東京に多 く, V P は福岡, 鹿児島と九州だけで 4 例が報告 されている，HCP新鼬と秋田で発見されてい る。一方，諸外国の例をみると，V Pは南アフリ カに多く, 南アフリカ型とも呼ばれ約8000例が発 見されて枋り，AＩＰはスウェーデン型とも呼ば れ，スウェーデンで 600 例が報告されている。ま たその頻度も $0.5 / 10$ 万〜 300/10万とばらつきは あるが，か胡高い，本邦の報告はまだ 100 例に も満たず，諸外国に比し，はるかに少ない，しか しながら、いずれの病型む優性遺伝であり，決定 
k. Screening tost

\begin{tabular}{|c|c|c|c|c|c|c|c|c|}
\hline & \multicolumn{4}{|c|}{ Why } & \multicolumn{4}{|c|}{ 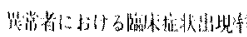 } \\
\hline \multirow{5}{*}{ AIP } & & \multirow{2}{*}{ 愎 } & \multicolumn{2}{|c|}{ 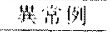 } & & 絞 & \multicolumn{2}{|c|}{ 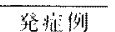 } \\
\hline & & & 例数 & $\%$ & & 数 & 例喽 & $\%$ \\
\hline & 9 & 62 & 20 & $\sqrt{32,3}$ & 为 & 20 & 3 & 15.0 \\
\hline & ty & 77 & 44 & 57.1 & $x$ & 44 & 22 & 50.0 \\
\hline & it & 139 & 64 & 46.0 & 10 & 64 & 25 & 39.1 \\
\hline \multirow{5}{*}{ HCP } & & 総 & \multicolumn{2}{|c|}{ 然营例 } & & 総 & \multicolumn{2}{|c|}{ 発在侧 } \\
\hline & & 数 & 例数 & $\%$ & & 数 & 例数 & $\%$ \\
\hline & 97 & 17 & 3 & 17.6 & 盟 & 3 & 0 & $\overline{0}$ \\
\hline & k & 42 & 28 & 66.7 & 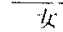 & 28 & 14 & 50.0 \\
\hline & it & 58 & 31 & 52.5 & it & 31 & 14 & $\overline{45.2}$ \\
\hline
\end{tabular}

的な治療法のない現在，早期獄断，早期治療とと もにスクリーニングによる潜在症の発見, 発病の 预防が大比上考它ら机る。

2）スクリーニングテスト（表 3）

先にわれわれはA I P㧍上びH C Pのポルフィ 1)ン排泄パターンを検討し, 緩解期 A I P は尿 $\mathrm{P}$ B G (11例平均19.8mg/日), $\mathrm{HC} \mathrm{P}$ は翼便 C P (8 例平均 $18.6 \mathrm{mg} /$ 日）が高值を持続することを想め, それぞれ緩解期の診断や潜在症の発見に役立つこ とを知つた。 そこでA I P は尿 P B G 検出 (Watson-Schwartz変法), H C P は筫便 C P 検出 (Holti 変法)を用いてスクリーニングを行なつた結果， A I P 6 家系，HCP7家柔が発見されたが，そ の分布ではAＩＰは新舅県中部に集中しており， H C P は佐渡, 上越地区，秋田県之明らかに異な つた。また患者家采に多数の潜在症が発見され， 全部でA I Pは 139名中64名 46\%が陽性であり, HCPは7家系59名中31名 $52.5 \%$ が陽性で, Weinbergの分離比はそれをれ0.471，0.472と

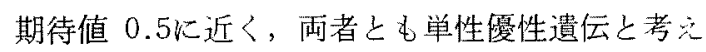
られた。また陽性者の中, 発症者は汕病型とも40 $\%$ 前後で著しく高い。さらに陽性者扎よび発症者 の出現率とも女性に高く，女性ホルモンで誘発さ れることなど考え合わせると女性に発現しやすい
要因が考えられた。

3）誘発試駿について

以上の定性試験陰性にもかか⿰力口加登病した例 や月経前期のみ高䛧を示した例があり，单なる定

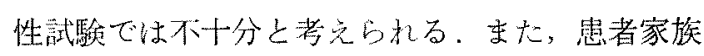
で定量すると定性試験陰性にもか力加らす゚两病型 とも正常值上界を上回る例がかなり認められ, 誘 発試験が必要と考觉られた。

そこでglycine (30mg/日), estrogen (ethinylestradiol $0.24 \mathrm{mg} / \mathrm{\theta})$, progesterone (19-nor17- $\alpha$-ethinyltestosterone 30mg/日), 拈よび $1-\mathrm{T}_{3}(150 \mu \mathrm{g} /$ 日) 负荷武駼を检討の結果，反応寺上び副作用の面上 りみて1-T 貝荷試験が最も上い結果を示した。 奏際に 1 - T 8 負荷試験で尿 P B Gが著増し, 初めて 確診し得た例尼経験した。かかるlatent chemical ともいうべき例が男性に多く諗められる点で興味 深いが，発症者も男性に少ないことなとから女性 の場合と逆に男性では臨床的にも代謝面で発現し にくい要因が教党られた。

\section{むすび}

急性ボルフィリン聇につき，自験例を中心に本 邦例を統括して述べた。

臨床上, 腹部症状, 神経症状, 精神症状の3 徵 が主体をな寸が不全型も多いことを述べるととも に, 黄便 C P の增加を特徽とする新病型hereditary coproporphyriaを報告し, 本症では尿 P B Gの みならず䔬便C P 検出も重要なことを指摘した。

また，患者家系比つきスクリーニングを行な

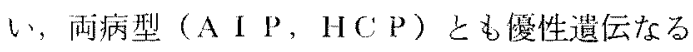
ことを明らかにし，导らに定性試駩陰性にもかか わらず，ポルフィリン体が高值を示すborderline case多数を認め，誘発試娩の必要なことを述べ た。 